\title{
The courtroom as TV studio: the case of the Oscar Pistorius trial
}

\author{
Dikgang Moseneke ${ }^{1 *}$ \\ ${ }^{1}$ Appointed to the Constitutional Court of South Africa in 2002, then Deputy Chief Justice in 2005 until retirement in 2016 \\ *Corresponding author. E-mail: makubande@gmail.com
}

\begin{abstract}
In 2014, something happened that changed how the media report on court proceedings in South Africa. The Oscar Pistorius trial proceedings attracted much media attention. International journalists flocked into South Africa in droves. Our newspapers, our televisions, our radios, even our Facebook feeds were flooded with information. An entire twenty-four-hour television channel was created with the sole purpose of televising, and then discussing, the proceedings. Everything about the trial - the judge's rulings, the witnesses who gave evidence and especially the verdict - clogged social-media newsfeeds on laptops and other devices for months on end. This has changed irreversibly the manner in which the media and the justice system in South Africa converge. Through a focus on the debates in and out of the courtroom that the Pistorius trial generated, this paper explores the intersection between the judicial function, the media and the public. It was an important moment in post-apartheid South Africa, ushering in a new way of making and distributing judicial images to the public and thereby bringing into being new ways for the media and the public to access and assess the adjudicative role of judges.
\end{abstract}

Keywords: South Africa; Oscar Pistorius; cameras; courtroom judges

\section{Introduction}

In 2014, something happened that changed how the media report on court proceedings in South Africa. The trial against Mr Oscar Pistorius, the Olympian blade runner, gained as much worldwide media attention as the disappearance of Malaysian Airlines flight MH370 - an event that has been described as 'the world's greatest aviation mystery' (Devlin, 2018). The trial inspired books, newspaper articles, TV channels, journal articles and blogs. ${ }^{1}$ Everything about the trial - the judge's rulings, the witnesses that gave evidence and especially the verdict - clogged social-media newsfeeds on our laptops and other devices for months on end. There can be no doubt that the Pistorius trial was of great interest, both at home and abroad. And it has changed irreversibly the manner in which the media and the justice system in South Africa converge. That prompted me to explore the intersection between the judicial function, the media and the public. My question is whether the trial has ushered in a new way in which the media and the public access and assess the adjudicative role of judges - a function that is tightly bound up with primal questions about personal liberty, fairness, judicial accountability and what an open and just society means under the rule of law.

In 2014, the digital winds of change were already sweeping across the corridors of the institutions of justice in South Africa. In that year, the Constitutional Court, the country's highest court, become the first court in Africa to have an active presence on Twitter, with a newly accessible audience of the five and a half million South African users. The UK and US Supreme Courts have been on Twitter for some time now. ${ }^{2}$ We are becoming part of that elite team of apex courts adapting to the modern age. The court's presence on Twitter is symptomatic of that change.

\footnotetext{
${ }^{1}$ For examples of scholarship on the media activity around the trial, see Grundlingh (2017); James (2017); Knight (2017).

${ }^{2}$ The United Kingdom Supreme Court Twitter account was created in October 2011, though the first official tweet was on 6 February 2012, reading 'Hello all, thanks for the warm welcome! We'll kick off at 11.30 with Lord Reed's swearing-in. How (c) Cambridge University Press 2018
} 
But tweeting aside, I would like to start by pondering over the time-honoured notion of 'open justice' drawn from the normative values of our rightly venerated South African Constitution. Most have no doubt heard the pithy quote: 'justice must not only be done, it must be seen to be done.' The fuller and original version of the quote is attributed to Lord Hewart C.J.: 'justice should not only be done, but should manifestly and undoubtedly be seen to be done.'

In this paper, I trace the concept of open justice across the lineage of South Africa. Then, I pause to look at the judicial response to the public and media clamour to have full access to the proceedings in the Pistorius criminal trial. That seminal response is to be found in the decision of Judge President Mlambo in Multichoice. ${ }^{4}$ That decision was delivered just ahead of, and as a result of, the imminent start of the Pistorius trial. The media houses made a big ask indeed from the courts. They posed serious questions about how our courts could better ensure the hallowed principle of open justice. The questions were many and complex but, even more intriguingly, they were new to the judicial system in South Africa. Should we let the reporters in? With more than their pens and little traditional note pads: with their smartphones, electronic notebooks and iPads? Why, then, shouldn't we let the cameras in as well? If we do, should the cameras relay to the world, instantly or at all, everything we say and do in court? Or should we rather have the cameras fixed on the judge only? Or should we perhaps restrict these digital technologies and jam the transmitting signal in the court houses?

With all that in mind, I would like to make a few observations about the new age we live in, and how, because of the rapid advancement of technology, our society is no longer one in which citizens must, or should have to, wander into courtrooms to find out what is happening. People want to see, and hear all in their places of work, in the comfort of their own homes and villages or indeed in other open spaces, so long as they have an active Internet connection. Finally, I evaluate the challenges to open justice as it faces the brave new world of limitless instant feeds that have the potential to make everything visible, everywhere by way of the media.

\section{The South African Constitution and open justice}

The principle of open justice is an incident of the values of openness, accountability and the rule of law, as well as a core part of the notion of a participatory democracy. All these are foundational values entrenched in the South African Constitution. Its preamble contemplates 'a democratic and open society in which government is based on the will of the people' and the text requires that our democracy shall ensure accountability, responsiveness and openness. ${ }^{5}$ The public is entitled to have access to the courts and to obtain information pertaining to them. ${ }^{6}$

In traditional African culture, the shade of a tree was the place where disputes of society were mediated and resolved. It was on this soil that the community would meet for a 'lekgotla'. There was room for all to have their say. Everybody was an active participant in the process. This is how justice was done: in the open, collaboratively and with an element of peer review. That was the age-old concept of open justice under a tree.

we'll use Twitter: bit.ly/AaGloB'. See https://twitter.com/UKSupremeCourt; a number of other countries' apex courts also have Twitter feeds; see Jackson and Shelly (2015).

${ }^{3}$ R. v. Sussex Justices, Ex parte McCarthy [1924] 1 KB 256; [1923] All ER 233, 259, per Lord Hewart C.J., as cited in Van der Walt v. Metcash Trading Limited [2002] ZACC 4; 2002 (4) SA 317 (CC); 2002 (5) BCLR 454 (CC), at para. 68. Note that the original reads: 'justice should not only be done, but should manifestly and undoubtedly be seen to be done.'

${ }^{4}$ Multichoice (Proprietary) Limited and Others v. National Prosecuting Authority and Another, In re: S. v. Pistorius, In re Media 24 Limited and Others v. Director of Public Prosecutions North Gauteng and Others [2014] ZAGPPHC 37 (Multichoice).

${ }^{5}$ See Chapter 1, clause 1, of the Constitution. See also South African Broadcasting Corporation Limited v. National Director of Public Prosecution, Schabir Shaik and Others [2006] ZACC 15; 2007 (1) SA 523 (CC); 2007 (2) BCLR 167 (CC) (Shaik), at para. 97.

${ }^{6}$ Section 34 of the Constitution of the Republic of South Africa, 1996 (Constitution). 
The aesthetics of the Constitutional Court building are a daily gentle reminder of this promise. The overarching theme of the court building as represented in the Constitutional Court's logo is justice under a tree. As former Justice Sachs described it: ' $\mathrm{t}$ ] he tree protects the people, and they look after the tree." This is symbolic of the synergy between the law and the people. It gives the court an organic ambience - a space where you feel welcome to see justice in motion. Courts play a vital role to solve conflicts in all spheres of life. This is what the Constitution promises us.

There are innumerable quotes, many of which evoke powerful imagery, about the ills suffered by a society that does not promote open justice. It does, after all, form part of the bedrock principles of a functioning democracy, and helps to quench the people's 'fundamental, natural yearning to see justice done'. ${ }^{8}$ The crispest and truest of these quotes is that '[d]emocracies die behind closed doors'. ${ }^{9}$ The principle of open justice is one that strikes at the very heart of what South Africa has been, and is still, trying to achieve in the post-apartheid era. We acknowledge a difficult truth: trust in government institutions in our country is hard-earned. If we do not subject ourselves to the greatest of scrutiny, how can we hope to persuade the public to recommence, or perhaps commence for the first time, that which was lost for so long: faith in the social contract. We can only move forward as a country when we voluntarily, if not happily, sacrifice certain liberties in return for the good that can be achieved in a representative democracy: uniform laws that apply to all, a social welfare system that protects the most vulnerable among us and institutional redress when our rights are compromised. Indeed, transparency of the judicial process is so fundamental to developing public trust: 'all other checks are insufficient [and] of small account. Recordation, appeal, [and] other institutions operate as [mere] cloaks [rather] than checks; as cloaks in reality, as checks only in appearance' (Bentham, 1827, p. 524).

The arguments in favour of open justice are discussed widely, but are perhaps best summarised in the following observation:

'First, it assist[s] in the search for truth and play[s] an important role in informing and educating the public. Second, it enhance[s] accountability and deter[s] misconduct. Third, it ha[s] a therapeutic function, offering an assurance that justice has been done [a sense of communal catharsis]. ${ }^{, 10}$

Of course, open justice is not a novel concept in South Africa, miraculously discovered in our lifespan as a constitutional democracy. The foundational nature of a public trial has been recognised since as far back as $1813 .{ }^{11}$ And, globally, the roots of the public trial have been 'traced back beyond reliable historical records, ${ }^{12}$ with the notion being incorporated into almost every international human rights instrument. $^{13}$

But what did happen recently, in 1994, was that the new Constitution came into force - a new South Africa was born. The old South Africa, tyrannical and unjust, was now impotent in its reign, while the new South Africa was full of hope and unconstrained potential. For open justice alone,

\footnotetext{
${ }^{7}$ On the architecture and symbolism of the post-apartheid justice system, see Le Roux (2004).

${ }^{8}$ Richmond Newspapers $v$. Virginia, 448 US 555, 571 (1980).

${ }^{9}$ Detroit Free Press v. John Ashcroft, 303 F.3d 681, 683 (2002).

${ }^{10}$ City of Cape Town v. South African National Roads Authority Limited and Others [2015] ZASCA 58 (Cape Town v. SANRAL), at para. 12. See also S. v. Mamabolo [2001] ZACC 17; 2001 (3) SA 409 (CC); 2001 (5) BCLR 449 (CC), at para. 29, in which the Constitutional Court held that open justice 'seeks to ensure that the citizenry know what is happening ... so that the people can discuss, endorse, criticise, applaud or castigate the conduct of the courts. ... [It also] promotes impartiality, accessibility and effectiveness, three of the important attributes prescribed for the judiciary by the Constitution'.

${ }^{11}$ Financial Mail (Pty) Ltd v. Registrar of Insurance and Others 1966 (2) SA 219 (W).

${ }^{12}$ Richmond Newspapers, note 8 above, p. 564. The United States Supreme Court in that case went as far as saying that 'although great changes in courts and procedure took place [since the 1300s], one thing remained constant: the public character of the trial at which guilt or innocence was decided'. Ibid., at p. 566.

${ }^{13}$ See, for example, Universal Declaration of Human Rights (1948), Art. 19 (freedom of opinion and expression); and International Covenant on Civil and Political Rights (1976), Art. 19.2 (freedom of expression).
} 
the Constitution guarantees the freedom of the press, the freedom of the media and the right of the public to receive and discuss information and ideas. ${ }^{14}$ It provides, in Article 34, 'a right to have any dispute that can be resolved by the application of law to be decided in a fair public hearing before a court or, where appropriate, another independent and impartial tribunal or forum'. Article 35 contains provisions relating to access to courts and a fair trial for those arrested and accused of criminal offences. ${ }^{15}$ The Constitutional Court itself is architecturally designed to both ensure, and represent, open justice. For example, the courtroom includes windows that open onto the street and a dedicated media box. The tree logo of the court and the artwork of clouds on the walls of the courtroom together are a constant reminder to those in the courtroom of the demands of doing justice under a tree. Consider this in comparison to the past, the old South Africa, with rampant practices of incommunicado detention, without any prospect of a proper trial. The old Terrorism Act $^{16}$ permitted a senior police officer to decide that a person should be detained without trial for up to sixty days, without any right to communicate with the outside world. While the act had the appearance of being 'designed to combat terrorism [it in fact] itself became an instrument of terror' (Dugard, 1978, p. 136).

There is also no shortage of comments about open justice from judges in the last twenty years, particularly when it butts heads with the right to a fair trial. In 2006, for example, the Constitutional Court was asked to decide whether it was acceptable for the Supreme Court of Appeal to restrict the media to purely visual recordings, with no audio. ${ }^{17}$ The matter was brought before us on an urgent basis, and almost exclusively because of that, and the desire not to rush such an important decision, most of the judges refused to allow the media to audio-record the proceedings. The now-retired Justice Albie Sachs said that he only refused the media's request in order to 'await the establishing of appropriately negotiated procedures for guaranteeing accurate, balanced and fair reporting. ${ }^{18}$ My dissenting minority judgment held fast that media ought to be allowed audio-video recording as no harm would ensue from recording and broadcasting argument of counsel before an appellate court.

The principle of open justice is, after all, a core part of the notion of participatory democracy. This is plain from our Constitution that begins with the very words 'democratic and open society'. ${ }^{19}$ It is not a principle that should be confined in haste. The public now rely on the public and social media to inform them. We do not want a system in which the judicial system is 'shrouded in mystique and protected at all times from the prying eye of the camera or the invasive ear of the microphone'. ${ }^{20}$ We want a system in which the public trusts that the judiciary is acting according to the 'time-honoured standards of independence, integrity, impartiality and fairness. ${ }^{21}$ For that to happen, we must, as far as reasonably practicable, create means for the media to access, observe and report on the administration

\footnotetext{
'Everyone has the right to freedom of expression, which includes-

(a) freedom of the press and other media;

(b) freedom to receive or impart information or ideas;

(c) freedom of artistic creativity; and

(d) academic freedom and freedom of scientific research.'
}

${ }^{14}$ Section 16(1) (freedom of expression) of the Constitution provides in relevant part:

See also Khumalo and Others v. Holomisa [2002] ZACC 12; 2002 (5) SA 401 (CC); 2002 (8) BCLR 771 (CC), at para. 22, in which the Constitutional Court held that ' $\mathrm{t}$ ] he media are key agents in ensuring that ... the [public's] right to receive information and ideas ... [is] respected'.

${ }^{15}$ Section $35(3)$ (c) (right to a public trial) of the Constitution provides: 'Every accused person has a right to a fair trial, which includes the right ... to a public trial before an ordinary court' (emphasis added). This provision is, to a large extent, realised via s. 152 of the Criminal Procedure Act 51 of 1977, which expressly requires all criminal proceedings to 'take place in open court'.

${ }^{16} 83$ of 1967 , particularly s. 6.

${ }^{17}$ Shaik, note 5 above.

${ }^{18}$ Ibid., at para. 135.

${ }^{19}$ Preamble to the Constitution of the Republic of South Africa, 1996, emphasis added.

${ }^{20}$ Shaik, note 5 above, at para. 33 .

${ }^{21}$ Ibid., at para. 32 . 
of justice. ${ }^{22}$ This right extends not only to the media having the facility to enter the courtroom, but also to having access to court papers and written arguments in hard copy or online.

\section{Multi-choice: enabling society a first-hand look in the courtroom}

This brings me to the watershed decision of Judge President Mlambo on how to strike a balance between openness and justice. The Oscar Pistorius trial posed trenchant questions about the real-life meaning of open justice. In September 2014, Mr Pistorius was found guilty of culpable homicide and a firearm offence, ${ }^{23}$ and sentenced to a maximum of five years' imprisonment. ${ }^{24}$ That conviction has since been replaced on appeal by a verdict of guilty of murder. After a number of appeals, in November 2017, he was finally sentenced by the Supreme Court of Appeals of South Africa to a period of imprisonment of thirteen years and five months. ${ }^{25}$

The Oscar Pistorius trial proceedings attracted much media attention. International journalists flocked into South Africa in droves. Our newspapers, our televisions, our radios, even our Facebook feeds were flooded with information. An entire twenty-four-hour television channel was created with the sole purpose of televising, and then discussing, the proceedings. The coverage was so extensive that one would have needed to sever all contact with the human world not to hear about the trial. All of this was made possible because, before the trial even began, Judge Mlambo did what no South African court had before dared to do: media organisations were given permission to broadcast, live and in full Technicolor, a criminal trial.

In reaching that decision, the judge recognised that, when two constitutional rights butt heads, such as the right to freedom of expression and the right to a fair trial, it is not a matter of determining which right is more deserving so that courts may declare a victor and jettison the loser. ${ }^{26} \mathrm{No}$, the true path is far more complex, and involves a balancing exercise to reconcile the two. ${ }^{27}$ The media in that case, unsurprisingly, argued that '[f]reedom of expression lies at the heart of a democracy ${ }^{28}$ and urged the court to 'exercise its inherent power to regulate its own' ${ }^{29}$ processes in order to permit the broadcasting of 'the entire criminal proceedings ${ }^{30}$ against Mr Pistorius. Mr Pistorius, on the other hand, contended that he, his counsel and his witnesses would be inhibited by the 'mere knowledge of the presence of audio visual equipment, especially cameras ${ }^{31}$ and that media coverage as sought would 'enable witnesses ... to fabricate and adapt their evidence based on their knowledge of what other witnesses have testified'. ${ }^{32}$

The court began by explaining that the question is not whether the media, be they electronic, broadcast or print, should be allowed to cover court proceedings, but how guarantees can be put

\footnotetext{
${ }^{22}$ See, for example, Independent Newspapers (Pty) Ltd v. Minister for Intelligence Services (Freedom of Expression Institute as Amicus Curiae) In re: Masetlha v. President of the Republic of South Africa and Another [2008] ZACC 6; 2008 (5) SA 31 (CC); 2008 (8) BCLR 771 (CC), at para. 41.

${ }^{23}$ S. v. Pistorius [2014] ZAGPPHC 793.

${ }^{24}$ S. v. Pistorius [2014] ZAGPPHC 924.

${ }^{25}$ The Director of Public Prosecutions, Gauteng v. Oscar Leonard Carl Pistorius (950/2016) [2017] ZASCA 158 (24 November 2017).

${ }^{26}$ Multichoice, note 4 above, at para. 18, citing Midi Television (Pty) Ltd v. Director of Public Prosecutions (Western Cape) [2007] ZASCA 56; [2007] 3 All SA 318 (SCA) (Midi Television), at para. 9.

${ }^{27}$ Ibid., at para. 15, citing South African Broadcasting Corporation Ltd v. Downer NO and Shaik [2006] ZASCA 90, at paras $14-15$.

${ }^{28}$ Ibid., at para. 6, citing South African National Defence Union v. Minister of Defence and Another [1999] ZACC 7; 1999 (4) SA 469 (CC); 1999 (6) BCLR 615 (CC), at para. 7.

${ }^{29}$ Ibid., at para. 9, citing South African Broadcasting Corporation Limited v. Thatcher and Others [2005] ZAWCHC 63; [2005] 4 All SA 353 (C), at paras 29 and 31, in particular relying on s. 173 of the Constitution, which grants superior courts the inherent power to protect and regulate their own processes, taking into account the interests of justice.

${ }^{30}$ Ibid., at para. 1.

${ }^{31}$ Ibid., at para. 12.

${ }^{32}$ Ibid.
} 
in place to ensure the public is indeed well informed about how the courts function'. ${ }^{33}$ The learned judge did not look favourably upon the potential situation in which only the 'small segment of the community ... [with] access to tools such as Twitter [are] ... able to be kept informed', ${ }^{34}$ particularly when '[our] democracy is still somewhat young and [there are still negative] perceptions that continue to persist in the larger section of South African society. ${ }^{35}$ But the court did concede the valid concerns of broadcasting visual images of Mr Pistorius and his witnesses, such that they may be 'disabled ... in giving [their] evidence, ${ }^{36}$ So the learned judge concluded that the audio of those witnesses could be broadcast, but no visual imagery. Ironically, this was the exact opposite of what was permissible in Shaik, in which visual imagery was permitted, but no audio. And so it was that Judge Mlambo struck a compromise, which he believed achieved open justice without improperly impinging on the fairness of the trial.

It was only four months later in the trial against Radovan Krejčír ${ }^{37}$ that we saw a similar order made, permitting media coverage of another trial. And already there was improved media freedom. In the Pistorius trial, the media was required to have their cameras installed seventy-two hours before the trial was set to begin, and those were to be controlled in a nearby room, with no cameramen permitted in the courtroom. ${ }^{38}$ But, in Krejčír, two cameras were allowed to be controlled by cameramen in the courtroom itself, so long as they did not move around the court while it was in session. ${ }^{39}$ Next, we must ask ourselves: should court orders be limited to discussing only cameras and microphones in the courtroom? Or should we begin to address intentionally the question of whether those in the gallery, including the media, should also be allowed to use their smartphones and laptops? If so, to what extent? Should live streaming be permitted, straight from the courtroom?

\section{Technology in the courtroom}

The question of technology in courts is a two-pronged question: what technology should the court itself use, and what technology should the court allow others to use? In response to the first question, we are making strides on that front. As I just said, we now have a Twitter account. We are also investigating the possibility of evolving into a completely paperless court. We are truly proud of the strides our Constitutional Court has taken to become substantially digital. It is compulsory for litigants to file court records in digital form alongside hard copies. All case records, pleadings, written argument, court judgments and orders are digital and may be accessed by the public from our website within minutes of their being issued. Parties, their lawyers and the public can track our case management online. In fact, our website is visited extensively and has thousands of hits from all over the world week after week. This has helped courts of other countries to draw from our judicial experience and their citizens to formulate their constitutional claims.

As to the second question of what technology people should be allowed to use in court, that was the question the learned Judge Masipa had to grapple with in the course of the Pistorius trial. Before one of the witnesses gave evidence, the judge prohibited reporters from tweeting or blogging about that witness's evidence. But then, only a day later, before that witness even gave evidence, the trial judge changed her mind and allowed all non-participants in court to tweet and blog to their heart's content. $^{40}$

\footnotetext{
${ }^{33}$ Ibid., at para. 20, citing Shaik, note 5 above, at para. 70 .

${ }^{34}$ Ibid., at para. 21.

${ }^{35}$ Ibid., at para. 27.

${ }^{36}$ Ibid., at para. 25.

${ }^{37}$ South African Broadcasting Corporation Limited v. Director of Public Prosecutions, South Gauteng High Court, Johannesburg and Others; In re: S. v. Krejcir and Others [2014] ZAGPJHC 241 (Krejcir).

${ }^{38}$ Multichoice, note 4 above, at Orders 2.2-2.3.

${ }^{39} \mathrm{Krejcir}$, note 37 above, at Order 4.4 .

${ }^{40}$ See http://www.iol.co.za/news/crime-courts/oscar-judge-allows-tweeting-blogging-1659305.
} 
A similar carte blanche approach has been taken in the UK for several years now. In December 2010, the judge hearing the bail proceedings against Wikileaks founder Julian Assange permitted reporters to tweet in the courtroom. ${ }^{41}$ A year later, the UK Supreme Court issued a formal direction permitting 'live text-based communications' such as e-mail and social media (including Twitter) in the courtroom, in order to better promote open justice. ${ }^{42}$ Journalists were urged to 'Twitter as much as you wish'. ${ }^{43}$ Now my law clerks tell me that it would have been more accurate to say 'Tweet as much as you wish', but the message remains clear: delayed information is as good as denied information. There is no reason not to, as a default position, permit live tweeting and whatever else from the courtroom. There is no logic in asking the media to step outside of the courtroom to press 'send'.

And, as for letting TV cameras into the courtroom, in the Constitutional Court, media houses do not need special permission to televise our proceedings live or delayed. One must, however, be careful here. There is a big difference between appellate proceedings where only seasoned advocates appear before appeal courts and trial proceedings where live testimony is heard from witnesses. It is indeed arguable that unmitigated publicity, particularly in relation to lay witnesses, may undermine the fairness of a trial. The search for the truth may fall victim to the 'you are on camera' syndrome. Having warned as I have, in most cases, live camera footage will be more accurate than a reporter's after-the-fact summary. Whatever account they give after they leave the courtroom will inevitably be a second-hand account, their interpretation bleeding into their report. More so, mischievously selected sound bites may indeed undermine accuracy and the important context within which the words were uttered.

\section{Challenges for open justice}

Setting aside, for a moment, our celebrations of the progress we have made in encouraging greater transparency in court processes, it is important to remember that open justice is not, and has never been, absolute. ${ }^{44}$ As I mentioned earlier, there are competing objectives, which must be reconciled. There are challenges, which must be tackled. Witness testimony might be altered if they see other witnesses testify. Witnesses might be intimidated by the presence of cameras. The last remnants of the sub judice rule may still prevent people from speaking outside of court while proceedings are still afoot. There is also a fear that the media might manipulate audio-visual recordings out of context and mislead the public perception, ${ }^{45}$ or, as just mentioned, that any summarised version of a case will be a second-hand account, susceptible to inaccuracies and interpretive 'spin'. 46

\footnotetext{
${ }^{41}$ http://www.theguardian.com/technology/2010/dec/14/twitter-allowed-bail-hearing.

${ }^{42}$ UK Supreme Court, Practice Guidance: The Use of Live Text-Based Forms of Communication (Including Twitter) From Court for the Purposes of Fair and Accurate Reporting, 14 December 2011. Section 9 of the Practice Direction does, though, limit the carte blanche use of live text-based communications. Members of the public that are not part of the media must directly apply to the judge, even if informally through court staff.

${ }^{43} \mathrm{http}: / /$ www.theguardian.com/law/2011/dec/14/judge-court-reporters-twitter.

${ }^{44}$ See, for example, Scott v. Scott [1913] AC 417 (HL), a seminal British case on open justice from over a century ago, in which the House of Lords held there to be three exceptions to holding court proceedings in public: cases affecting 'lunatics', cases affecting wards of the court and cases where a public trial would defeat the entire purpose of the proceedings, such as those involving trade secrets. See in particular pp. 437 (per Viscount Haldane), 441 (per Earl of Halsbury) and 480 (per Lord Shaw of Dunfermline), as discussed in A. v. British Broadcasting [2014] UKSC 25, at para. 29.

${ }^{45}$ Multichoice, note 4 above, at para. 19, citing Shaik, note 5 above, at para. 68, in which the Constitutional Court held that '[s] ound bytes from political discourse, sometimes played over and over again on television ... carry the very real risk of trivialising complex issues and converting what should be public education into public entertainment'. The Supreme Court of Victoria in Australia seems to overcome this hurdle by providing their own audio-visual recordings of important decisions. See that court's website, which provides 'live, or on demand, video and audio webcasts of sentences and judgments' at http:// scv2.webcentral.com.au/sentences/.

${ }^{46}$ Multichoice, note 4 above, at para. 21.
} 


\section{Media presence: effect on witnesses}

The first challenge for open justice is the effect of media presence on witnesses. We must diligently guard against the possibility that witnesses might change their testimony. This might be a simple matter of their memory of events being subconsciously changed by what they see and hear in the media. In the Pistorius trial itself, witnesses all but confessed to being glued to their televisions. ${ }^{47} \mathrm{I}$ am by no means saying that this affected their testimony. The concern, rather, is that we cannot safely say that it did not affect their testimony. There is also the prospect of witnesses consciously changing their tune in response to media presence. The media's presence subjects witnesses to potential intimidation, both from others and from within themselves. Public speaking is, after all, feared by some more than death.

But these concerns are not enough to warrant closing the courtroom doors to reporters and cameras. To prevent the possibility of witness intimidation, we would quite literally need to bar everyone from the courtroom except the litigants in every trial and subject them to stringent gag orders. Open justice demands quite the opposite.

There are myriad measures available to protect witnesses. These range from anonymity orders to protect vulnerable witnesses' identities ${ }^{48}$ and allowing witnesses to testify through intermediaries ${ }^{49}$ or with the help of a support person, ${ }^{50}$ to closing the courtroom so that only certain people are present, ${ }^{51}$ or even allowing witnesses to testify from a remote location via closed-circuit television. ${ }^{52}$ Other measures might include suppression orders such as that ordered in Multichoice when Judge Mlambo prohibited the media from photographing or broadcasting the testimony of Mr Pistorius or his witnesses, ${ }^{53}$ or even, as the US has started experimenting with, allowing witnesses to wear disguises in court. ${ }^{54}$

\section{Sub judice rule: dead as the dodo?}

In order to address the potential pitfalls of media presence in the courtroom, justice systems around the world have done what lawyers do best: they have created exceptions to a rule, the rule here being open justice. But not all of these operate in South Africa.

What may still operate in South Africa, though, is the principle of sub judice, which literally translates as 'under judgment'. It refers to a prohibition on publicly discussing what happens in a case until the case is finalised. In America, the rule manifests itself in the lawyers' ethical rules, prohibiting them from making statements outside of court that will be publicly broadcast and might affect the outcome

\footnotetext{
${ }^{47}$ Wardle (2014) notes that 'witness after witness in the Pistorius trial [has] confess[ed] to having been glued to their television screens' (p. 27).

${ }^{48}$ See, for example, Central Authority for the Republic of South Africa v. K. [2014] ZAGPJHC 373, at para. 63 (ordering anonymity of the parties to 'protect the interests of the child') and H. v. S. [2014] ZAGPJHC 214, at paras 1-2 (ordering anonymity because '[a]side from being a minor, as she grows up her self-esteem and dignity may be unnecessarily affected if she perceives that those who she comes into contact with are aware of her identity').

${ }^{49}$ See, for example, s. $170 \mathrm{~A}$ of the Criminal Procedure Act 51 of 1977, which permits witnesses 'under the biological or mental age of eighteen ... to give his or her evidence through [an] intermediary'.

${ }^{50}$ This is, unfortunately, a protection that is currently only given to accused persons under the age of eighteen, allowing a parent or guardian to assist them, as per s. 73(3) of the Criminal Procedure Act 51 of 1977. Witnesses and victims are not yet legislatively entitled to a support person. See, for example, H. Galgut, In camera hearings, closed circuit television, support persons and vulnerable witnesses, Gender Law Unit, Sonnenberg, Hoffman \& Galombik, noting that '[a]t present, no statutory provision is made for the appointment of a designated support person to accompany and thereby provide emotional support'.

${ }^{51}$ See, for example, s. 153 of the Criminal Procedure Act 51 of 1977, which protects vulnerable persons by giving the judge the discretion to prohibit people from being in the courtroom if the alleged offence involves a sexual offence or extortion.

${ }^{52}$ See, for example, s. 158 of the Criminal Procedure Act 51 of 1977, which gives courts the discretion to allow evidence to be given by means of closed-circuit television or similar electronic media.

${ }^{53}$ Multichoice, note 4 above, at Orders 4.3 and 5.10 .

${ }^{54}$ See, for example, United States v. Jesus-Casteneda, 705 F.3d 1117, 1119 (9th Cir. 2013) (holding that allowing a witness to testify in disguise does not necessarily violate a defendant's rights).
} 
of the proceedings. ${ }^{55}$ But how, you might ask, can a statement outside of court affect the outcome of a case in South Africa, where we have no jury system $?^{56}$ The answer must surely be that it rarely could, and that the sub judice rule, and its relevance in South Africa, is, at the very least, on the verge of extinction.

The pedigree of the rule has yet to reach the Constitutional Court, but the Supreme Court of Appeal in 2007, in a case that did not even use the word sub judice, significantly narrowed the scope of the rule. ${ }^{57}$ After a crime of horrific proportions, which I needn't detail here, the media and public's attention was grabbed. A documentary was made, and the Director of Public Prosecutions sought an order prohibiting its broadcast before the trial on the basis that it would hinder the integrity of the administration of justice. ${ }^{58}$ First, the documentary might demonstrate inconsistencies in witness testimony that could be used to discredit them at trial. Second, witness safety may be compromised if their identities were released to the public. The court hearing the matter considered these pitfalls to be, at best, conjectural. If there were discrepancies, all the better that the light be shone upon them, earlier rather than later. And the witnesses' identities were already public knowledge. The court therefore followed authorities from England, ${ }^{59}$ Canada $^{60}$ and Australia ${ }^{61}$ and concluded that

'a publication will be unlawful, and thus susceptible to being prohibited, only if the prejudice that the publication might cause to the administration of justice is demonstrable and substantial and there is a real risk that the prejudice will occur if publication takes place. ${ }^{.62}$

As you can see, in that decision, the sub judice rule has been whittled down considerably. About that I say nothing now. Let it be enough to observe that the social and other media blasts and immediacy make the sub judice rule nearly impossible to hold and to keep, for better or for worse. What is more, it will be near impossible for the courts to police the rule. And, as you know, what the courts cannot police cannot be enforced.

\section{The media's highest obligation: accuracy}

Finally, perhaps the greatest challenge to open justice, as much as it is also its greatest strength, is the role of the media in reporting on the judicial function. We, the people and the Constitution, have not afforded the media freedom of the press as a privilege to enjoy. Public media is entrusted with a sacred duty - one that, if not properly carried out, could eviscerate our democratic project. Public media are charged with the role of being a conduit - as they inform, educate and entertain. Their agency role of

\footnotetext{
${ }^{55}$ American Bar Association Model Rules of Professional Conduct, rule 3.6(a).

${ }^{56}$ See, for example, Kriel, Social media in court [2013] De Rebus 52, at p. 7, such that one would 'need to show that a tweet creates a real risk that substantial and demonstrable prejudice to the administration of justice [would occur]. It would be very difficult to show that a judge would be swayed by commentary on Twitter. In South Africa, we do not have the added problem of a jury system'.

${ }^{57}$ See Midi Television, note 26 above.

${ }^{58}$ Ibid., at paras 5 and 22.

${ }^{59}$ Attorney-General v. British Broadcasting Corporation [1981] AC 303; [1980] 3 All EWR 161, at 362 (holding that 'the prior restraint of publication, though occasionally necessary in serious cases, is a drastic interference with freedom of speech and should only be ordered where there is a substantial risk of grave injustice') and Attorney-General v. Times Newspapers Ltd [1974] AC 233; [1983] 3 All ER 54, at 299A, per Lord Reid and 303B-C, per Lord Morris (holding that a ban on publication to protect the administration of justice would be allowed only if there was a 'real risk [of prejudice], as opposed to a remote possibility').

${ }^{60}$ Dagenais v. Canadian Broadcasting Corporation (1995) 25 CRR. (2d) 1, at 47 (holding that a publication ban could only be ordered if there was a 'real and substantial risk of interference with the right to a fair trial').

${ }^{61}$ Hinch v. Macquarie Broadcasting Holdings Ltd v. Attorney General for the State of Victoria [1987] HCA 56; (1987) 164 CLR 15, at para. 32 (holding that a publication would only amount to contempt if there was a 'substantial risk of serious interference with the trial').

${ }^{62}$ Midi Television, note 26 above, at para. 19.
} 
the public media is by now well embedded to the extent that the public, as consumers of news, feed off their reportage.

Open justice is all for nought if the media do not accurately convey what happens in the courtroom. Mistakes have been made. Even in the Pistorius trial itself, some analysts incorrectly cited the provisions of section 77 of the Criminal Procedure $\mathrm{Act}^{63}$ as applying, suggesting that a question had been raised about whether Mr Pistorius could understand the proceedings. It was actually sections 78 and 79 that were brought into question and whether some mental illness or mental defect impacted his criminal responsibility. ${ }^{64}$ Other mistakes have been of a more trivial nature, but are nonetheless important not to make. For example, two separate media outlets recently got names of some justices of the Constitutional Court wrong when reporting on a judgment ${ }^{65}$ last year. ${ }^{66}$ We are by no means a flock of prideful egos, but we would prefer the media got our names right. It is fair to ask that, in carrying out their responsibilities, the media worship at the altar of factual accuracy.

In addition to ensuring mistakes are not made, the media must also be careful not to sensationalise cases and turn them into media circuses. For example, on 16 January 2012, a headline appeared in the Pretoria News that read 'Judge okays child sex': a very misleading headline, to say the least. ${ }^{67} \mathrm{We}$ cannot condone a situation in which a witch-hunt or jarring sensationalism is traipsing around in the guise of open justice.

\section{Media coverage of court proceedings since the speech}

The trend of letting cameras into courtrooms has increased in trial and appellate courts. ${ }^{68}$ Bail proceedings ${ }^{69}$ and murder trials ${ }^{70}$ have been streamed live from courtrooms to televisions, computers and smartphones. So too was the state's appeal against the culpable-homicide conviction of Oscar Pistorius. ${ }^{71}$ Live television coverage was also provided of an appeal against a High Court decision about South Africa's obligations under international law to arrest and surrender to the International Criminal Court the President of Sudan. ${ }^{72}$ The media have also shown up, cameras and microphones in tow, at the Constitutional Court. This was for the hearing and later the judgment hand-down of a matter concerning the legal status of the powers of the Public Protector and whether the president of the republic was bound by remedial action taken by her that would see him paying back into the public purse some of the costs of non-security renovations at his private residence. ${ }^{73}$

\footnotetext{
${ }^{63} 51$ of 1977.

${ }^{64}$ See Wardle, note 47 above.

${ }^{65}$ Democratic Alliance v. African National Congress and Another [2015] ZACC 1; 2015 (2) SA 232 (CC); 2015 (3) BCLR 298 (CC), a case that ironically protected freedom of expression.

${ }^{66}$ Justice Bess Nkabinde was 'Jess' Nkabinde, and Justice Johan Froneman was 'Coenraad' Froneman (his middle name) in the article from January 2015. See http://mg.co.za/article/2015-01-19-da-sms-ruling-a-landmark-judgment. And Justice Van der Westhuizen was referred to, twice, as Justice van der Merwe in an another article from January 2015. See http://iolmobile. co.za/\#!/article/da-victory-deserved-but-judgment-sloppy-1.1806815.

${ }^{67} \mathrm{http}$ //www.iol.co.za/news/crime-courts/judge-okays-child-sex-1.1452575\#.VS5evfC4ddw. Note, though, that there was a retraction and apology the next day on 17 January 2012 that read: 'The Pretoria News wishes to retract the main headline ... which, we believe, sensationalised a sensitive issue. ... We acknowledge the headline could have been better phrased and regret the inappropriate wording of the poster.'

${ }^{68}$ See James (2017).

${ }^{69}$ Panayiotou v. S. [2015] ZAECGHC 73 (28 July 2015), in which case a businessman who paid for the abduction and murder of his wife appealed to the High Court against a magistrates' court refusal to grant him bail. The bail hearing was also televised.

${ }^{70}$ The murder trial of a woman who stabbed and killed her boyfriend, a famous South African hip hop artist. Judgment was handed down on 9 December 2015 and sentencing proceedings were on 10 March 2016. See http://ewn.co.za/2015/12/09/ Flabba-case-Judgment and http://mg.co.za/article/2016-03-10-flabbas-girlfriend-jailed-for-12-years.

${ }^{71}$ Director of Public Prosecutions, Gauteng v. Pistorius [2015] ZASCA 204; 20161 All SA 346 (SCA) (3 December 2015).

${ }^{72}$ Minister of Justice and Constitutional Development and Others v. Southern African Litigation Centre and Others [2016] ZASCA 17 (15 March 2016).

${ }^{73}$ Economic Freedom Fighters v. Speaker of the National Assembly and Others; Democratic Alliance v. Speaker of the National Assembly [2016] ZACC 11 (31 March 2016).
} 
Exceptional care had to be exercised by the media in covering a case involving the kidnapping of a new-born baby who was reunited with her biological family almost two decades later. ${ }^{74}$ She had recently found out that the person she considered her mother was not her biological mother, but rather her kidnapper. Media houses had to strike a sensitive balance between respecting the interests of a vulnerable young woman and telling the public about the goings-on of a case that generated heavy reaction. This time, and with good reason, the proceedings were not televised. Film reels rolled again during court proceedings initiated by Ms Winnie Mandela to contest the will of the late President Nelson Mandela. ${ }^{75}$ These are just a handful of examples that demonstrate the development of the principle of open justice through camera lenses in just under a year after this speech was first delivered. And it all started with that cutting-edge decision in Multichoice. ${ }^{76}$

\section{Conclusion}

All this to say we, the media and the courts, share a common goal. We want the public to know. Indeed, it is our shared responsibility to ensure that they do. The trial against Oscar Pistorius may have attracted great media attention, but it is the decision in Multichoice that will set a trend for many years to come. It has paved the way for us to begin reassessing how to achieve open justice in the technological age.

My caution to us all is that, in doing so, we must not blindly ignore the potential risks: inaccurate or sensationalised reporting or intimidation of witnesses. So, while the technology is new and the language has changed, our judicial task remains the same: a meticulous balancing exercise between many competing rights, which can only be protected through carefully considered guidance and instructions from the presiding judge in each case.

\section{References}

Bentham J (1827) Rationale of Judicial Evidence: Specially Applied to English Practice: In Five Volumes, Vol. 5. London: Hunt and Clarke.

Devlin A (2018) Plane mystery: what happened to flight MH370, what's the latest news on the Malaysia Airlines plane and is the search still going?, The Sun, 18 April. Available at https://www.thesun.co.uk/news/2100795/flight-mh370-malaysia-airlines-latest-news-search/ (accessed 24 April 2018).

Dugard J (1978) Human Rights and the South African Legal Order. Princeton: Princeton University Press.

Grundlingh L (2017) Identifying markers of sensationalism in online news reports on crime. Language Matters 48, $117-136$.

Jackson M and Shelly M (2015) The use of Twitter by Australian courts. Journal of Law, Information and Science 24, 83-100.

James AAW (2017) South Africa's debut into broadcasting criminal trials: the legal arguments in television the Oscar Pistorius trial. Potchefstroomse Elektroniese Regsblad/Potchefstroom Electronic Law Journal (PER/PELJ) 20, 1-21.

Knight M (2017) The accused is entering the courtroom: the live-tweeting of a murder trial. Journal of Media Practice 18, $186-211$.

Le Roux W (2004) Bridges, clearings and labyrinths: the architectural framing of the post-apartheid constitutionalism. $S A$ Public Law 19, 629-664.

Wardle B (2014) The sub judice rule and the Oscar Pistorius case: will the crime of contempt of court ex facie curiae become abrogated by disuse? De Rebus 543, 27. Available at http://www.derebus.org.za/sub-judice-rule-oscar-pistorius-case-willcrime-contempt-court-ex-facie-curiae-become-abrogated-disuse/ (accessed 23 April 2018).

\footnotetext{
${ }^{74}$ Judgment was delivered on 10 March 2016 (see http://www.news24.com/SouthAfrica/News/waves-kisses-as-zephanykidnapper-taken-into-custody-20160310).

${ }^{75}$ Judgment was handed down in the Mthatha High Court on 7 April 2016. http://www.sabc.co.za/news/a/ dcf5b1804bde41d89b0c9f96fb2bb898/Madikizela-Mandela\%E2\%80\%99s-battle-for-Qunu-home-to-continue-in-high-court20160103. See also BREAKING NEWS: Winnie Madikizela-Mandela loses claim to Qunu house - Times LIVE.

${ }^{76}$ Multichoice, note 4 above.
}

Cite this article: Moseneke D (2018). The courtroom as TV studio: the case of the Oscar Pistorius trial. International Journal of Law in Context 14, 493-503. https://doi.org/10.1017/S1744552318000204 